\title{
FARM SIZE AS A FACTOR OF EMPLOYMENT AND INCOME OF MEMBERS OF FAMILY FARMS ${ }^{I}$
}

\author{
Petar Munćan², Dragica Božič̉
}

\begin{abstract}
Summary
Based on data collected through a survey of 35 family farms in Vojvodina, specialized in the market-oriented agricultural production, the interdependence of the size of family farm and structure of field crop production was studied, and its impact on the employment of permanent members actively employed in agriculture and their income. It was found that with an increase of farm size from 20 to $100 \mathrm{ha}$, the utilization of the available fund of working hours of active members increases by almost 2 times. In addition, with an increase in the size of the farm and increase in the share of industrial crops in the structure of field crop production, income per active member of the family household employed in agriculture also exhibits a tendency to increase. Income per active member, on the farms of 50-100 ha, is 3.6 times higher than the income generated on farms of 10-20 ha in size.
\end{abstract}

Key words: family farm, structure of production, active family farm members, employment, income

JEL: $Q 12, R 29$

\section{Introduction}

According to the data obtained in the Census of Agriculture in 2012, in Serbia, total of 628,552 family farms are registered, and 1,416,349 persons are engaged in agricultural activities as members of family farms (households), or full-time employees on the family farms. Employment in agriculture, as well as the scope and structure of the labour force of family farms are decisive factors for the dynamics of structural changes in agriculture and

1 Paper represents a part of the research on the project „Serbian Rural Labor Market and Rural Economics - Revenue Diversification and Poverty Mitigation”, No. ON179028, financially supported by the Ministry of Education, Science and Technological Development of the Republic of Serbia, period 2011-2014.

2 Petar Munćan, Ph.D., Full Profesor; University of Belgrade, Faculty of Agriculture Belgrade-Zemun, 011 2615-315 e-mail: muncan@agrif.bg.ac.rs

3 Dragica Božić Ph.D., Full Profesor; University of Belgrade, Faculty of Agriculture Belgrade-Zemun, 011 2615-315 e-mail: bozdrag@agrif.bg.ac.rs

EP 2017 (64) 4 (1483-1498) 
its overall development. The importance of the analysis of labour force and employment of family farm members derives from the fact that these studies provide important information on how to use the available labour resources on the farm, the labour productivity in agriculture and the importance of individual sources of income and their stability, as well as many other important aspects of the functioning of the family households as basic socio-economic unit in the rural areas, i.e. villages (Bogdanov, Babović, 2014). Analysis of the labour force and employment on family farms is very complicated, taking into account the specificities of agricultural production and a pronounced seasonality (a large number of workers engaged in a relatively short period of time). Due to the significant share of persons who are partially (seasonal and part-time) working on the farm, labour force in agriculture can be successfully analysed on the basis of data on the annual work units (Božić, Munćan, 2015). The total number of annual work units (equivalent of persons employed full time throughout the year) on family farms in 2012 was 618,054. Family labour force has a dominant share measured by this indicator, it amounts to about $95 \%$ ( $46 \%$ are carriers of family households and $49 \%$ of other family members).

More than $1 / 4$ of the farm members and persons employed in agriculture, annually are engaged in agricultural activities with less than half of full-time work (Bogdanov, Babović, 2014). Relatively low utilization of available labour force indicates that the Serbian agriculture is dominated by work extensive type of agriculture specific for small farms. Previous statement is confirmed by the results of the Agricultural Census in 2012, according to said source, farms of 5 ha make up about $78 \%$ of the total number of family farms and dispose with $30.5 \%$ of utilized agricultural land. Farms of over 10 ha make up only $8.1 \%$ of farms in Serbia, using $47.7 \%$ of utilized agricultural land listed in the Census. The largest farms, with over 50 ha, make up only $0.9 \%$ of the total number of family farms and dispose with about $19 \%$ of utilized agricultural land. Therefore, the average economic size of family farms, expressed as the total value of the standard output of the farm is only 5,492 Euros and is lower by 4.6 times in relation to the economic size of the EU-27 farm, which is 25,450 Euros (Eurostat). The average economic size of family farms, observed by regions of the Republic of Serbia, is the largest in Vojvodina and is double the Serbian average, but nevertheless is 2.2 times lower than the EU27 average (Božić, Munćan, 2015). Given the importance of family farms in terms of available resources, workforce and land use, the research subject in this paper are family farms and their available workforce. The starting point in the paper is the assumptions that with an increase in the size of the family farm and the share of industrial crops in the sowing structure, the volume of members' employment and the size of their income exhibit a tendency of increase. The aim of the research is to study the interdependence of the impact of farm size and different structure of the crop production to the extent of engagement of the available workforce and the level of income per family farm member.

\section{Data Sources and Methods}

The data collected by interviewing 35 family farms, focused solely on field crop 
production from the area of the region of Vojvodina ${ }^{4}$, was used as the main source of data for this research. Determination to focus on the region of Vojvodina comes from the fact that the results of the Census of Agriculture in 2012 showed that this region, compared to whole Serbia, and individually with the other three regions, is characterized by the following characteristics: substantially greater average size of family farm; the lowest share of family farms below 5 ha of utilized agricultural land; the highest share of farms with over 50 ha; the highest average economic size of farms, the most significant share of farms with only agricultural income. The major part of the agricultural production of the Republic of Serbia is realized on the territory of AP Vojvodina. In this area, on average, about $52 \%$ of the total area under grain and more than $92 \%$ of the area under industrial plants are sown (Bošnjak, Rodić, 2010). In addition, the classification of farms according to the type of production ${ }^{5}$ indicates that of the five types of specialized farms, in the region of Vojvodina, $40.8 \%$ are specialized for field crop production (Cvijanović et al., 2014). In a survey of family farms engaged exclusively in the production of field crops from the area of the region of Vojvodina, during production years 2011/2012, 2012/2013, 2013/2014, 2014/2015 and 2015/2016, the data were collected that were used for this study. The survey covered family farms of 10-100 ha of arable land, with four main arable crops (maize, wheat, sunflower and sugar beet) present in the structure of production. These crops are considered to be basic, major crops due to the fact that, during the survey period $2011-2016$, annually on average about $75 \%$ of arable land of family farms in the region was used for their production. The questionnaire includes the following data: number of active members of the family farms engaged exclusively in agriculture, used arable land, number of tractors and combines, production value and variable costs and basic technical and technological parameters on the farm.

All surveyed family farms are classified according to the size/surface of the area of arable land used in the three interval groups (10-20 ha, 20-50 ha and 50-100 ha).

In the calculation of the value indicators, the five year (2012 to 2016) average prices realized on the surveyed family farms were used. Average prices were used in order to avoid the extreme impacts of natural conditions on yields and annual fluctuations in the prices of inputs and outputs that occur as a result of disturbed relations in the market.

According to the sources and characteristics of the data, the methods of analysis and comparison are used in this paper, as well as the usual mathematical-statistical methods for analyzing important indicators of conditions and business results (Vidović,

4 Region is statistical, functional, territorial unit, consisting of one or more areas, established for the purpose of planning and implementing regional development policy, in accordance with the nomenclature of statistical territorial units at level 2, not administrative territorial unit and has no legal personality; Law on Regional Development "RS Official Gazette", No. 51/09.

5 Type of agricultural production of the farm is the farm production system characterized by the relative contribution of different activities/operations (production lines) in the total standard output of the farm (Cvijanović et al., 2014)

EP 2017 (64) 4 (1483-1498) 
Milunović, 2017), economic size and employment of the workforce of surveyed family farms, depending on the farm size, and the research results are presented graphically.

\section{Resources of surveyed family farms}

The average area/surface of utilized arable land owned by the surveyed family farms was 23.98 ha and ranged from 14.23 to 53.55 ha. In regard to the area/surface of utilized arable land taken on lease, the average area of surveyed family farms was 39.67 ha. The average area of utilized arable land taken on lease was 15.69 ha and ranged from 0 ha to 55.23 ha, and it was established that with an increase in the size of the farm, the share of arable land taken on lease in the total arable land of the farm also increases (Graph 1). The results of the earlier research conducted on 24 family farms in the area of the two municipalities of South Banat district confirm that smaller farms use only their own arable land, while in case of farms with up to 50 hectares of land, leased land accounts for 53\%, and in case of the largest farms with up to 100 ha, leased land accounts for about $66 \%$ of the total arable land used (Munćan, 2011). Similar results were obtained in the research conducted on 30 family farms on the territory of Vojvodina, according to which the smaller farms of 10-20 ha, are using only their own land, while in case of farms with over 20 ha, leased arable land contributes with over $50 \%$ in the total used arable land (Todorović, 2014). These proportions indicate that an increase in the size of family farms, in the study area, is largely achieved by leasing the arable land.

Graph 1. The ratio of used arable land owned and leased by the surveyed family farms

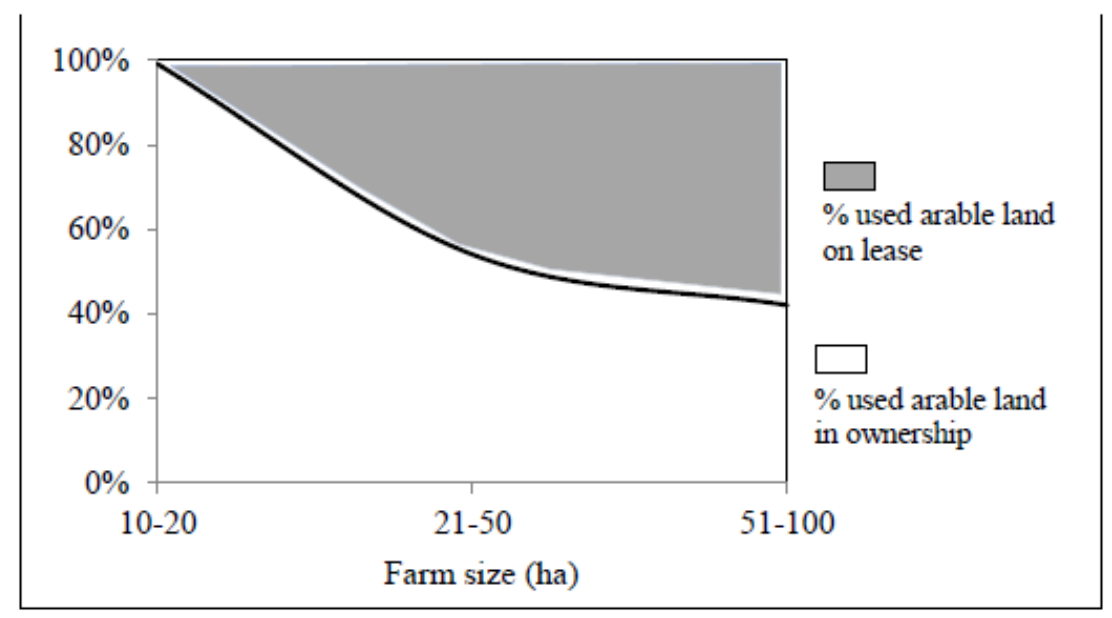

Source: author's calculation based on survey data

For the functioning of family farms, operation/work is a key element of a combination of production factors, and thus has a decisive influence on the achieved results (Mihajlović, 2016). Labour force of family farms is the most important input in agricultural production as it constitutes an active factor of land use and capital. Its deficiency is usually the limiting factor for the rational exploitation of other resources on the farm; while on the other hand, the surplus of labour force causes insufficient utilization of available working hours, i.e. their insufficient employment. 
Members of family farms, by their number and activity, determine not only their overall development but also the development of agriculture in general. The main characteristic of surveyed family farms was the dominant share of family farms with less than 3 members engaged exclusively in agriculture. Farms with least land had the least number of active members who are engaged exclusively in agriculture, on average 1.54 while the biggest farms had average 3.48 active members. With the increase of size of the used arable land, the total number of active members engaged exclusively in agriculture also increases (Graph 2).

Graph 2. The number of active members who are engaged exclusively in agriculture on surveyed family farms

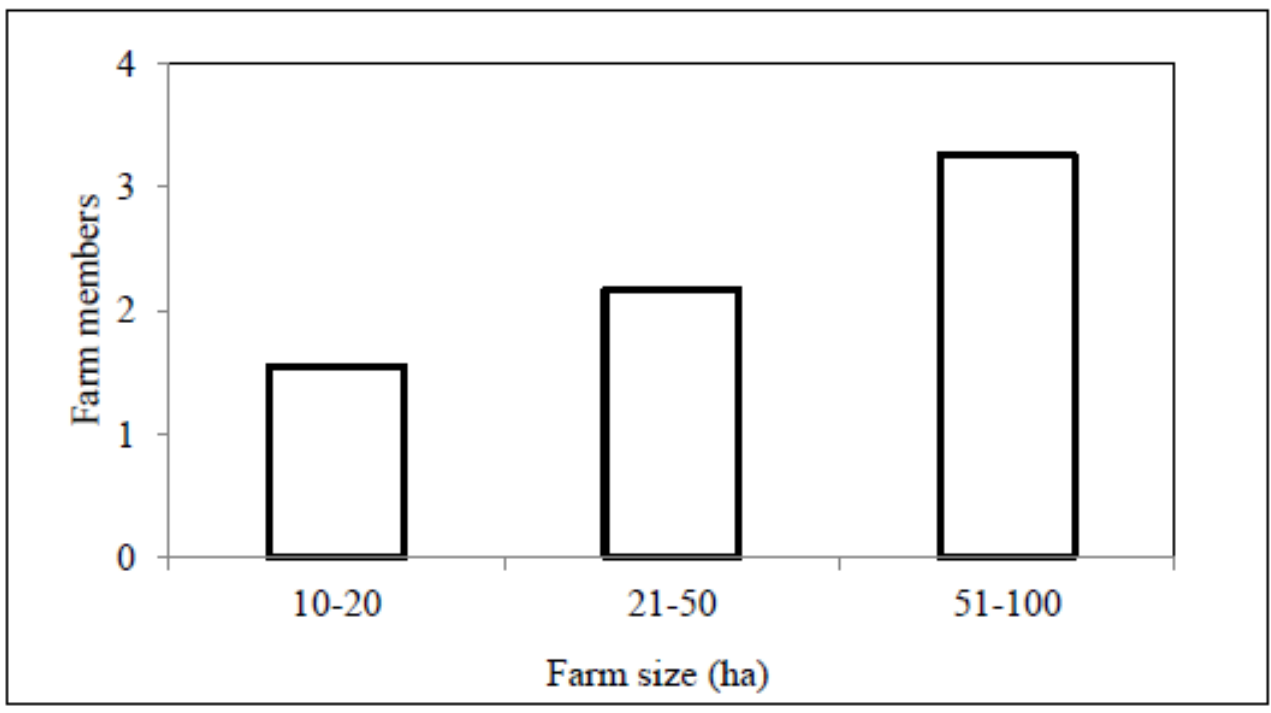

Source: author's calculation based on survey data

Consolidation of land in ownership carries with it changes in employment on farms. It is known rule that with the increase in farm size, the number of active members who are full-time working on the farm increases, and the number of active members who are permanently employed outside their own farms decreases. This fact suggests that the largest farms can experience labour deficit, while smaller farms on the other hand are not able to employ all active members working on the farm, so that some of them are forced to look for work outside the farm, i.e. to seek additional sources of income outside of their own farm (Todorović et al., 2009).

With an increase in the size of arable land the degree of engagement of the workforce increases observed from the perspective of the area of the used arable land per active member of the household engaged exclusively in agriculture (Todorović et al. 2011). It may be noted that most members of the family farms work on the farms of 50-100 ha. Thus, for most of surveyed family farms, area of arable land per active member of the household engaged exclusively in agriculture was little over 2.7 times higher 
than the same indicator on the smallest farms. The least favourable ratio of the area/ surface of used arable land and the number of active household members engaged only in agriculture, is observed in the smallest farms and is improved with the increase in the size of the farm (Graph 3). The increase of the area of arable land used by an active member of the household who is engaged exclusively in agriculture, in the surveyed farms, offers the opportunity to fully use available resources from the aspect of working time in agriculture.

Graph 3. Arable land per active member engaged exclusively in agriculture

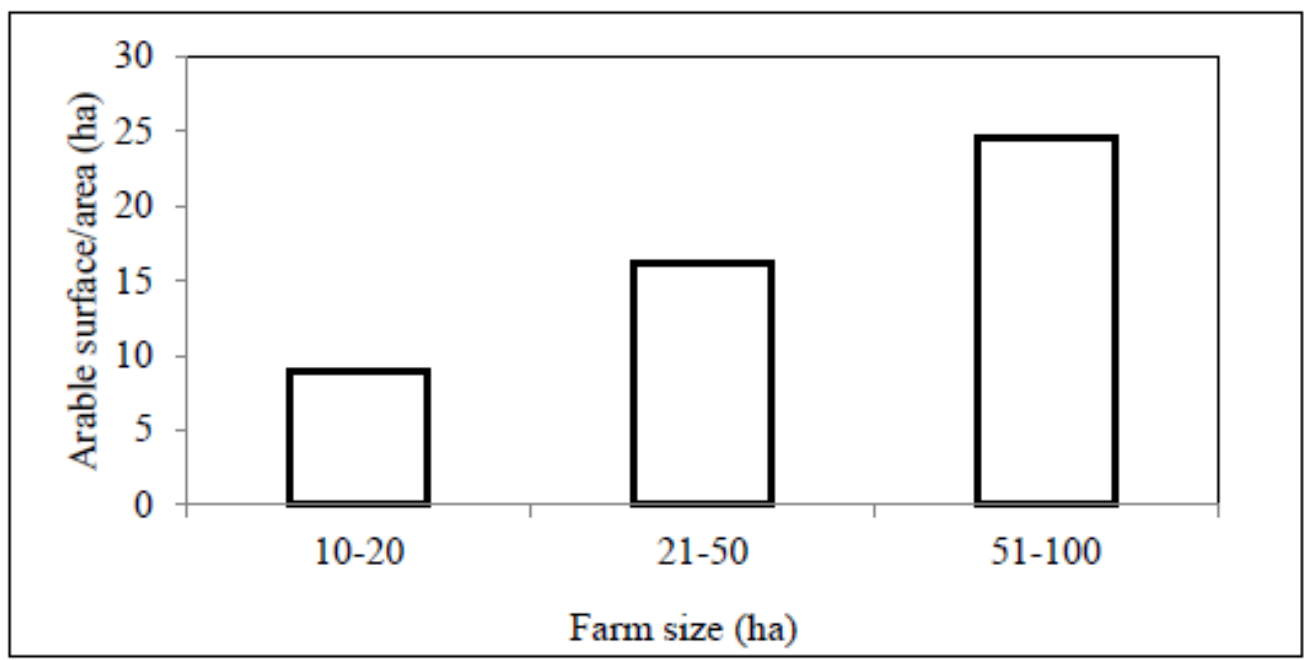

Source: author's calculation based on survey data

Agricultural machinery, as an important factor of production, plays an important role in the process of agricultural production. Its importance is both of technical and organizational-economic character, as tractors, combine harvesters and other auxiliary agricultural machines allow a more rational use of available natural and other resources, increase production volume and productivity, and enable relative reduction of production costs. For evaluation of energy equipment of family farms, the presence of important equipment, such as tractors and combines as the main source of mechanical energy in agriculture, is very significant. The average number of tractors per surveyed farm was 1.73 , indicating that almost $90 \%$ of the surveyed farms own more than one tractor. The remaining $10 \%$ of the surveyed farms owning only one tractor belong to the group of the smallest farms of 10-20 ha. Certain farms, size 20-50 ha and all of the farms of 50-100 ha, own the universal harvester, while none of the surveyed farms possess sugar beet harvesters. All surveyed farms have the necessary auxiliary agricultural machines for the realization of technology of field crop production present on the farm. On average 16.54 hectares of arable land per single tractor, with a variation of 9.42 ha in case of the smallest family farms 10-20 ha, to 25.14 ha in case of the largest farms (Graph 4). 
Graph 4. The surface/area of arable land of surveyed family farms by tractor

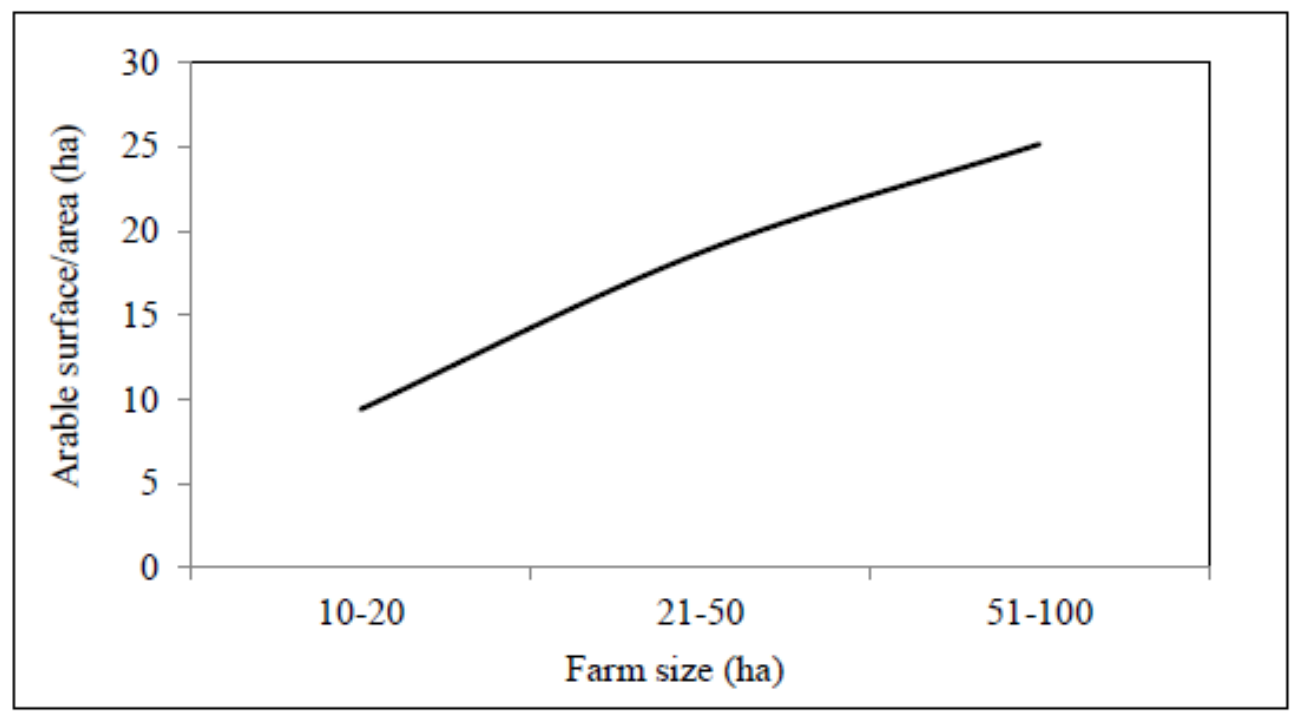

Source: author's calculation based on survey data

If we observe $\mathrm{kW}$ per ha of arable land, then it is possible to speak about the good equipment, because the average energy equipment of surveyed farms was $3.42 \mathrm{~kW}$ per ha which is very close to the average level specified for some EU member states (Heinrich, 2001; Kovacs et al. 2003).

\section{Operating results of the surveyed family farms}

The main characteristic of the sowing structure of surveyed family farms of all sizes is the dominant share of grain (maize and wheat) and a slightly lower share of sunflower and sugar beet as a representative of the group of industrial plants (Graph 5). The share of grain is dominant in the sowing structure of farms up to 20 ha and ranges up to a maximum of $80 \%$, while in case of farms over 50 ha, share of grain is lower primarily due to the fact that the sunflower and sugar beet also appear in the structure of sowing of these farms. The smallest farms show the lowest share of industrial plants, only $19 \%$, while in case of the largest farms, this share was $41 \%$ in the structure of sowing of arable land (Munćan et al. 2014). With regard to the production of industrial plants (sunflower and sugar beet), a certain tendency in the sowing structure is observed. The participation of this group of crops increases with the increase of farm size. The smallest surveyed farms, the size of up to 20 hectares, have the lowest share of the industrial plants, about $18 \%$, while in case of the large farms industrial plants are included in the sowing structure with over $30 \%$. This tendency can be explained by the fact that larger farms are better equipped with mechanization which allows them more efficient implementation of the technology of production of industrial crops, particularly sugar beet, which only appears in the structure of sowing on farms over 50 ha. 
Graph 5. The structure of sowing of surveyed family farms

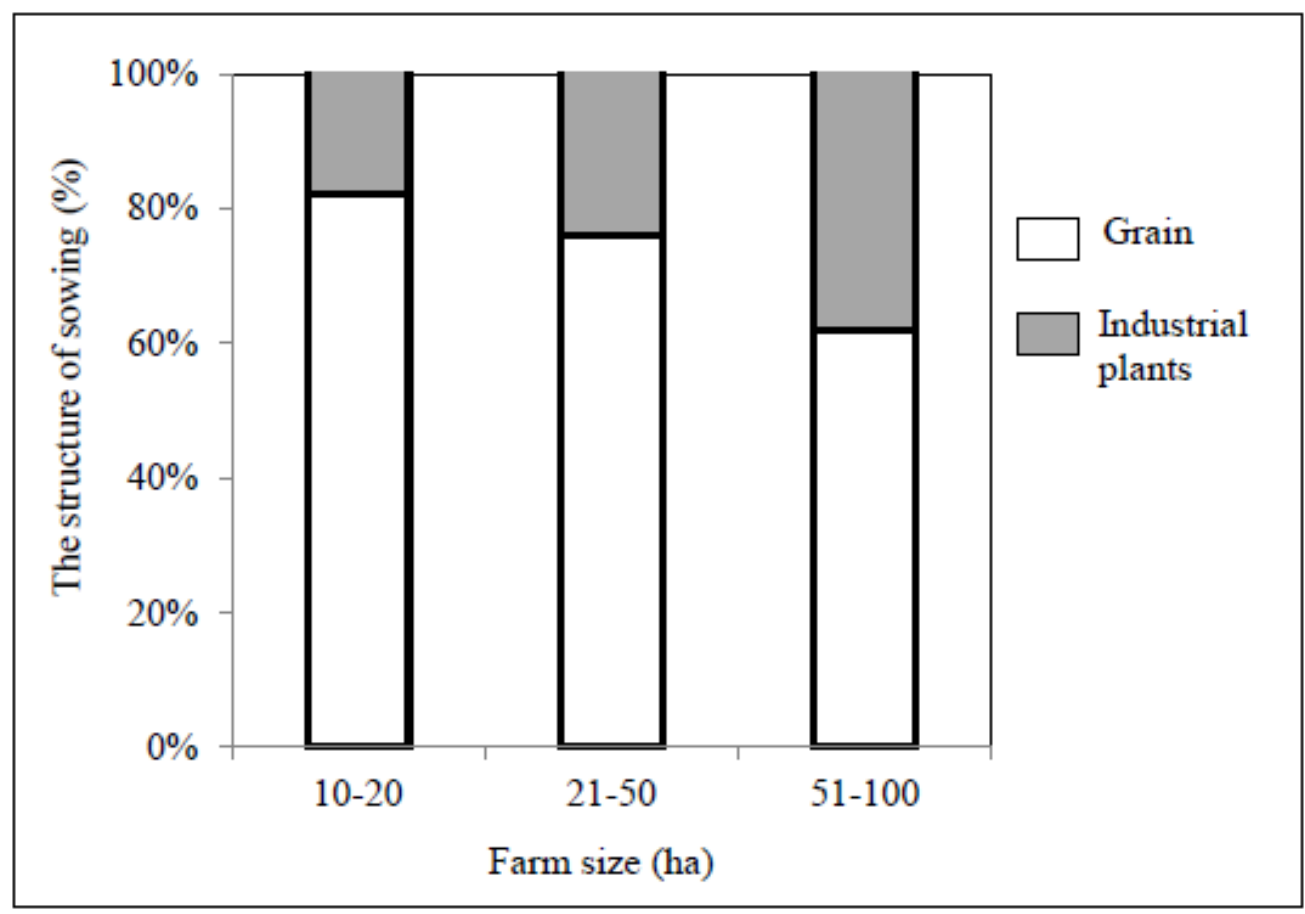

Source: author's calculation based on survey data

Different levels of intensity of production, caused primarily by the size of family farms, are responsible for the presence of significant differences in the realized grain yields on surveyed family farms (Graph 6).

Although the surveyed family farms have realized slightly higher yields than the average in Vojvodina, depending on the farm size and the types of crops, these yields are still by 20 to $130 \%$ lower compared to yields achieved in developed European countries. The reason for this is primarily in relatively low intensity of production of basic field crops, especially on surveyed small family farms. The increase of the level of intensity of production has very much a favourable impact on the increase of yield of these crops. However, the rise in prices of raw materials and fuel in the reporting period had adverse effect on the level of intensity of production, so that producers, in conditions of expensive production inputs, attempting to secure income, reduce agricultural technology and produce at the expense of natural resources, which is socially unacceptable (Bošnjak, Rodić, 2010). In the current conditions, part of the surveyed family farms were unable to provide the necessary financial resources which resulted in a decrease in the level of investment, and therefore the level of realized grain yields. For these reasons, the gross margin was used as the main indicator of economic efficiency of production of basic field crops on surveyed family farms. Gross margin is the difference between the realized value of production and total variable costs (seed, fertilizer, plant protection products, own services of tractors and combines, the costs 
of using the services of the combine on small farms, etc.). The realized gross margin at the farm level greatly affects the overall performance because all fixed costs of family farms are deducted of this amount in order to calculate the income. Given that the fixed costs are constant, any change in the breakeven margin at farm level in the short term has a direct impact on the amount of income. Positive breakeven margin contributes to covering of fixed costs and therefore, as pointed out by Ivkov et al. (2008), maximizing of gross margin is equivalent to maximizing profits or minimizing losses.

Graph 6. Average yields of major field crops of surveyed family farms

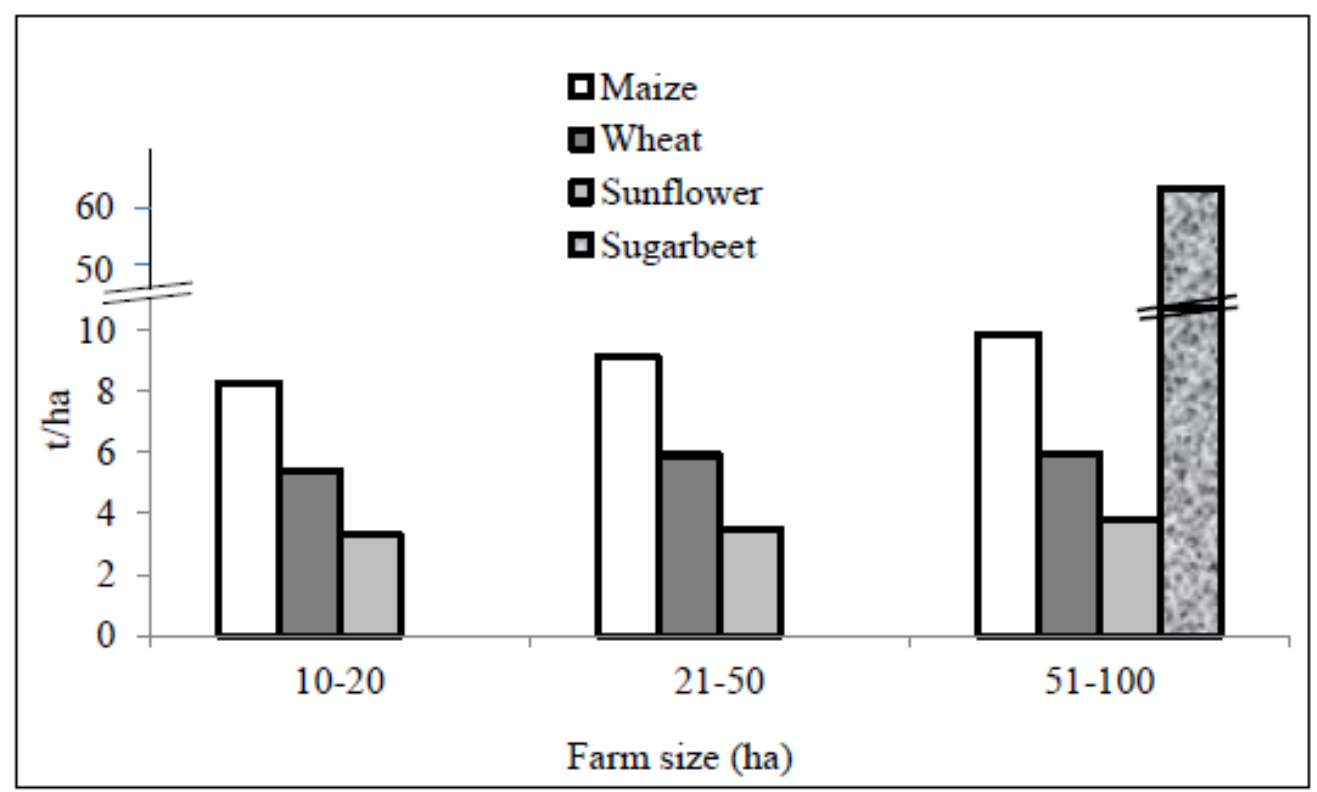

Source: author's calculation based on survey data

Given that the gross margin at the level of family farm depends on the farm size and structure of sowing, based on the representation of the analysed crops in the sowing structure of surveyed family farms, the average contribution of each of them in forming of the gross margin was determined, at the farm level and during the observed period. The main characteristic of the structure of the gross margins on the surveyed farms of all sizes is the dominant share of grain (maize and wheat), ranging from $82 \%$ for the smallest farms to $62 \%$ for the largest farms. Maize is the dominant crop with about $50 \%$ of the share when it comes to the structure of the gross margin of the surveyed farms of any size, whereas, the highest share of wheat on the smallest farms was $30 \%$ (Graph 7). The share of industrial crops (sunflower and sugar beet) in the structure of gross margin increases with the increase of farm size. 
Graph 7. The share of crops present in the overall gross margin of the surveyed family farms

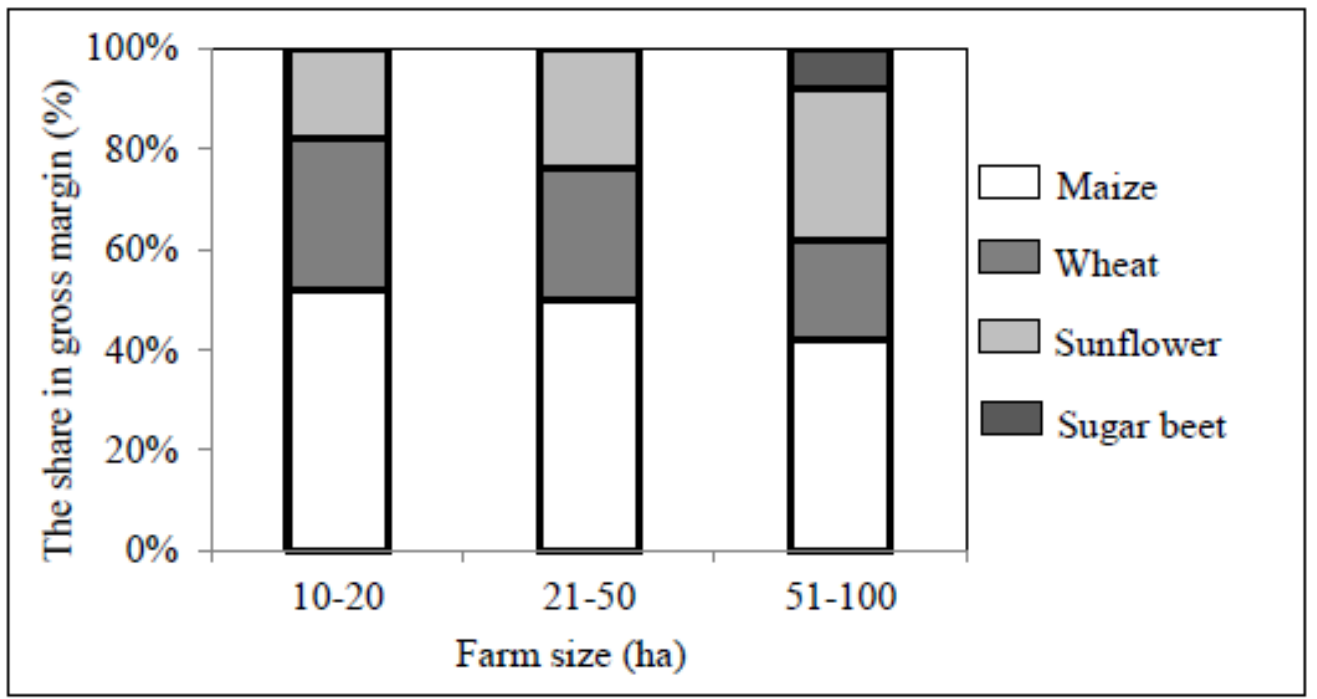

Source: author's calculation based on survey data

\section{Employment and the generated income of members of surveyed family farms}

Utilization of available workforce on family farms engaged exclusively in field crop production varies greatly during the year. By reviewing the time distribution of labour consumption by months on family farms engaged in the field crop production, Munćan et al. (2008) have come to the conclusion that the labour peaks occur in April and October, considering that these are periods of intense work in field crop production, and this is the case only on farms over 45 ha in October, and farms over 70 ha in April. With this in mind, it is clear that the labour deficit in the season, under certain circumstances, can be an obstacle to the rational use of other production factors and limiting factor for further growth of the largest surveyed family farms. On the other hand, the problem of utilization of available labour resources - active members of household ${ }^{6}$, who are engaged exclusively in agriculture, occurs on small family farms. Namely, insufficient size of family farms is one of the limiting factors of exploitation of available labour resources and presence of significant untapped potential of workforce on them (Graph 8). On the other hand, the utilization/exploitation of the available fund of working hours on the largest surveyed farms was almost 2 times higher than the utilization of the available working hours of members of the smallest family farms. This fact suggests that the increase of the size of farms certainly has big impact on increasing the employment of the active members of the household who are engaged exclusively in agriculture.

6 The available labour resource of members of surveyed farms is calculated as the product of 8 hours of work per day and 225 working days a year. 
Graph 8. The utilization of the available fund of working hours of active members engaged exclusively in agriculture

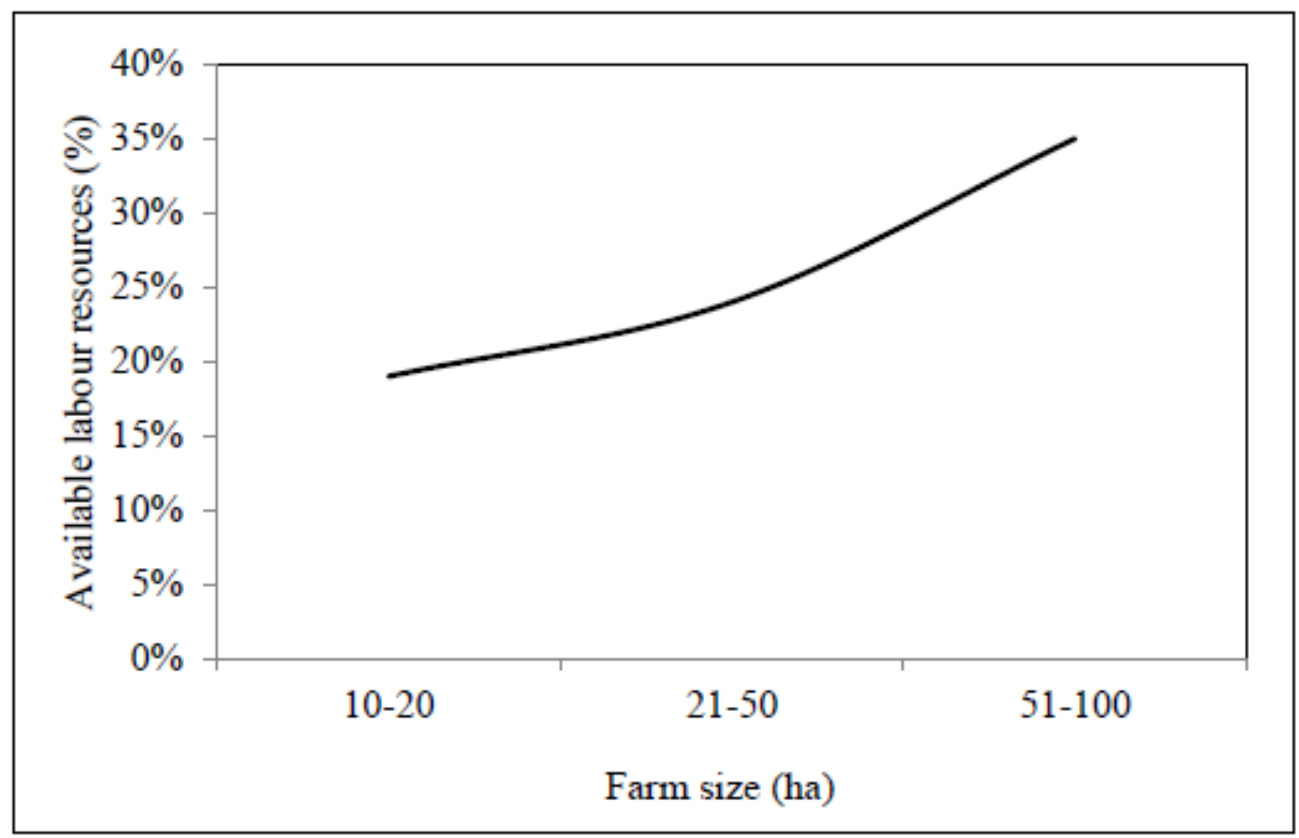

Source: author's calculation based on survey data

However, the scope of employment of the active members of the household does not depend solely on its size, but also on other factors such as the structure of field crop production on the farm, the level of technical equipment of farms, the intensity of field crop production, etc. For example, greater share of grain in the structure of sowing (which is typical for smaller farms) requires greater involvement of the workforce at the time of sowing and harvesting, while at other times during the year there are significant unused resources/reserves of available workforce. On the other hand, with increasing share of industrial plants in the structure of production, in particular sugar beet, the scope of employment/engagement of available labour force increases (Graph 9).

The income of surveyed family farms is calculated as the difference between the value of the total yield and the sum of the external costs of materials, services, depreciation of buildings and plant machinery, cost of insurance of products and instruments of labour, lease of land, interest on loans, property taxes and various taxes and fees (social security fees and taxes, taxes for pension and disability and health insurance, water fees, etc.). In this particular case, the income represents the difference between the revenue realized on the farm and total farm expenses, and shows how much a farm can spend in a certain period, without reducing its property (Gogić, 2014). 
Graph 9. The utilization of huma labour in production of major field crops in surveyed family farms

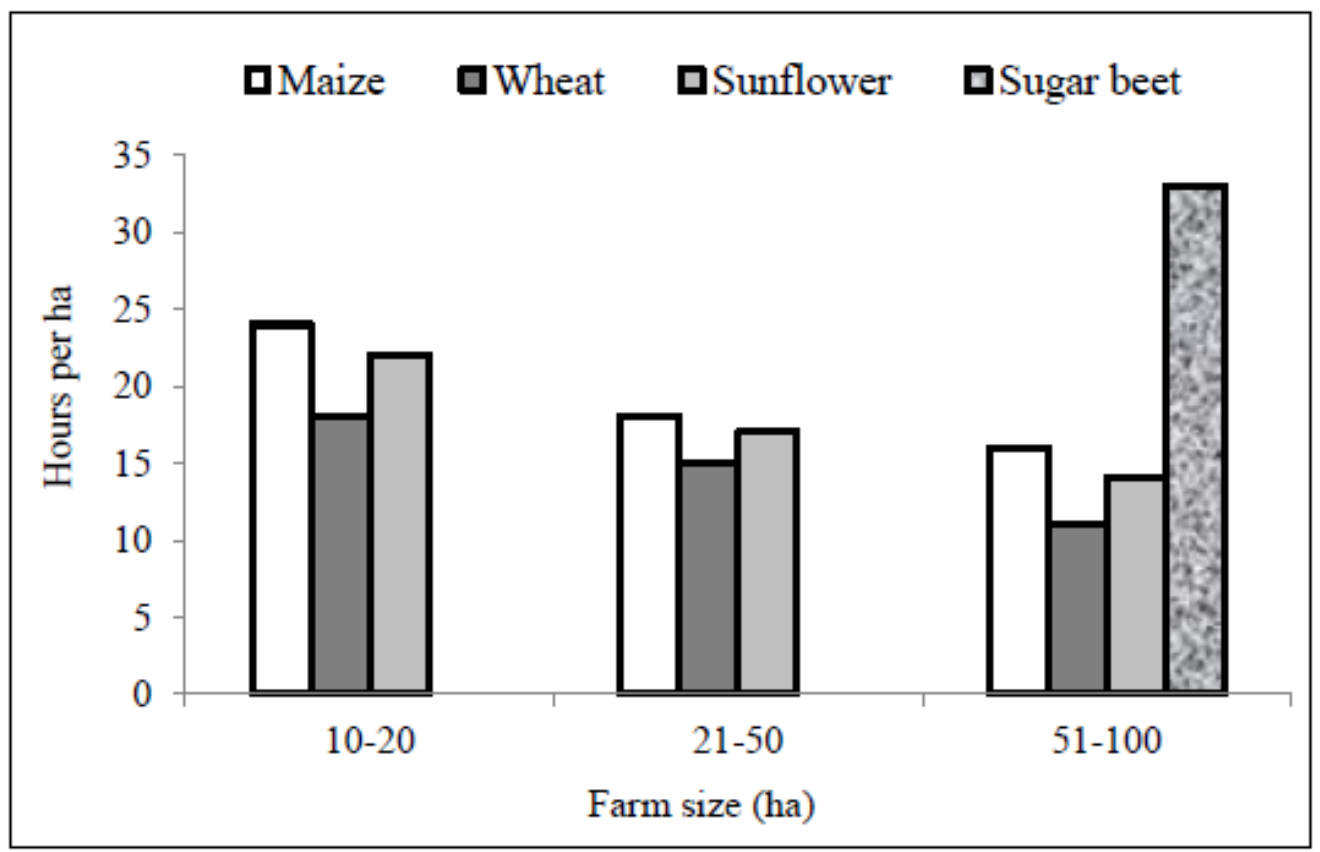

Source: author's calculation based on survey data

With an increase in the size of the farm and by changing the structure of field crop production, i.e. increase in the share of industrial plants in the sowing structure, income per active member employed full-time in agriculture exhibits a tendency of increase (Graph 10). The realized value of the income per active member is higher on farms of 20-50 ha by 2.15 times, and in case of farms of 50-100 ha even 3.6 times compared to income realized on farms of 10-20 ha (Graph 10). To which extent the level of generated income will satisfy the needs of active members of the family household fully employed in agriculture, largely depends on the socioeconomic environment in which the family farms operate because it determines how much income is enough to cover living expenses. The cash outflows for personal use and needs were considered as the cost of living in the present study, which in fact represent household expenditures according to the following groups: Food and non-alcoholic beverages; Alcoholic beverages and tobacco; Clothing and footwear; Housing, water, electricity, gas and other fuels; Furniture, household equipment and household maintenance; Health care; Transport; Communications; Recreation and culture; Education; Restaurants and hotels; Other goods and services. The cost of living accounted for in the present way is given in dinars per household member, ensuring their comparability with the income. 
Graph 10. The income per active member of the household engaged exclusively in agriculture and living expenses

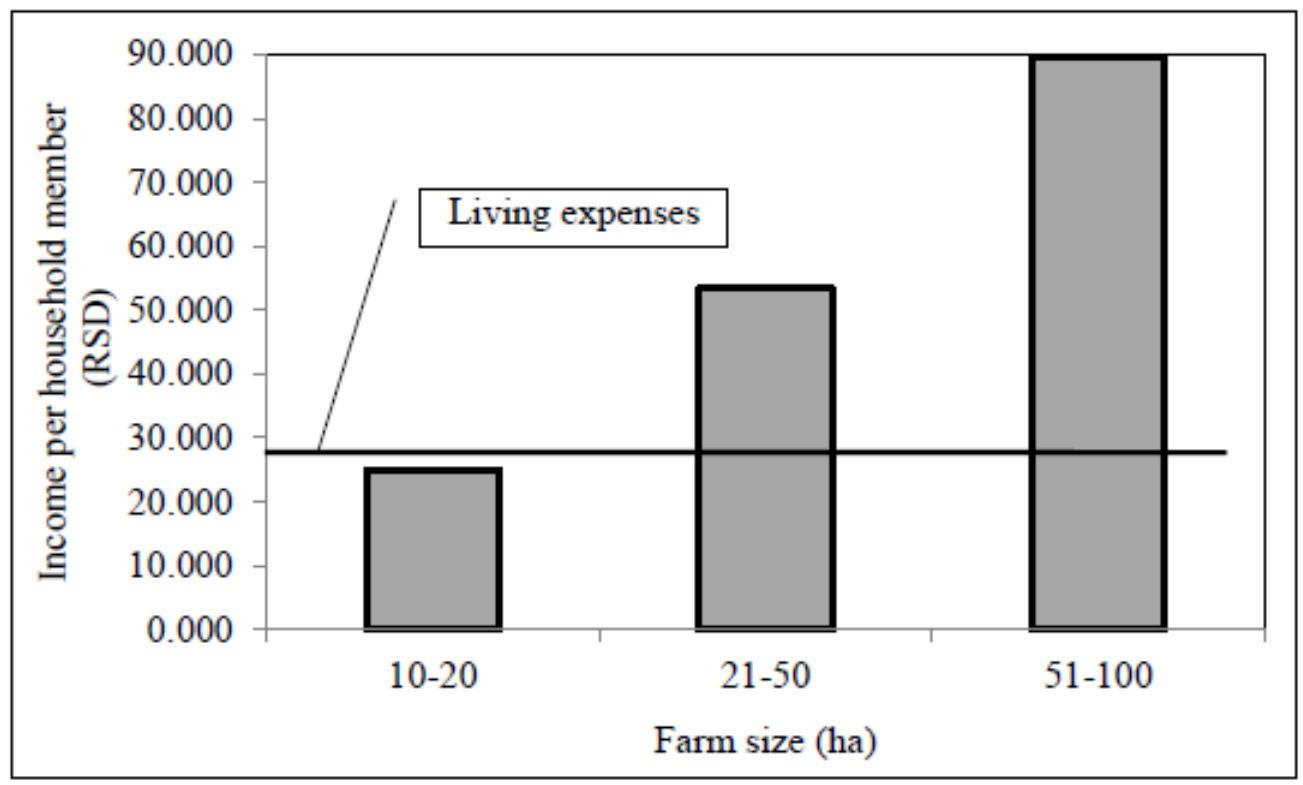

Source: author's calculation based on survey data

The income per active member of the surveyed farms who are engaged exclusively in agriculture is the lowest in the smallest farms and does not cover personal expenditure (Duffy, 2009). Survival in agriculture for these farms is possible by changing the structure of production (introduction of intensive vegetable or fruit production). The measures and instruments of the agricultural policy should be adapted to the specific needs of these farms. The latest reform of the CAP for the period 2014-2020, despite the introduction of basic payment scheme per hectare and two forms of compulsory direct payments (green and payments for young farmers), other payment schemes are introduced, including support for small farms with insufficient income (European Commission, 2016).

\section{Conclusion}

Family farms in Serbia, as well as in the surveyed region of Vojvodina, have significant workforce resources often not sufficiently and uniformly employed throughout the year. Also they own the largest areas of arable land which is additionally increased by taking land on lease, but this option is available only to larger, economically stronger farms. Larger farms are better equipped with mechanization which allows them more efficient implementation of the technology of production of industrial crops (especially sugar beet, which only appears in the structure of sowing on farms larger than 50 ha) and intensive production enables them to realize higher yields.

Income per active member of the surveyed farms that is engaged exclusively in agriculture is the lowest in farms with least land and does not even cover the expenditures 
for personal consumption, which makes these farms uncompetitive and they can not survive without significant support from the state. These farms can not guarantee greater employment of their members and can be expected to gradually disappear in the coming period.

\section{References}

1. Bogdanov, N., Babović, M. (2014): Radna snaga i aktivnosti poljoprivrednih gazdinstava (ISBN 978-86-6161-122-3), Republički zavod za statistiku, Beograd.

2. Bošnjak, D., Rodić, V. (2010): Komparativna analiza troškova proizvodnje osnovnih ratarskih useva u Vojvodini. Ekonomika poljoprivrede, br. 2, str. 233243, Beograd.

3. Bošnjak, D., Rodić, V. (2010): Konkurentnost osnovnih ratarskih useva u Vojvodini, Ratarstvo i povrtarstvo, Vol. 47 No. 2, pp. 607-612, Institut za ratarstvo i povrtarstvo, Novi Sad.

4. Božić, D., Munćan, P. (2015): Regional aspects of structural changes of family holdings in the Republic of Serbia, Economics of Agriculture No 1, page 107-122, Belgrade.

5. Cvijanović, D., Subić, J., Paraušić, V. (2014): Poljoprivredna gazdinstva prema ekonomskoj veličini i tipu proizvodnje u Republici Srbiji (ISBN 978-86-6161-122), Republički zavod za statistiku, Beograd.

6. Duffy, M. (2009): Economies of Size in Production Agriculture, Journal of Hunger\&Environmental Nutrition. 2009 Jul; 4(3-4): 375-392. Published online 2009 Dec.11 (http://www.tandfonline.com/doi/abs/10.1080/19320240903321292)

7. European Commission (2016): Review of Greening after One Year.SWD (2016) 218. Brussels: Commission of the European Union.

8. Gogić, P. (2014): Teorija troškova sa kalkulacijama u proizvodnji i preradi poljoprivrednih proizvoda (ISBN 978-86-7834-207-3). Poljoprivredni fakultet, Beograd.

9. Heinrich, I. (2001): Which kind of technology is suitable in the reform countries? U IAMO and Institute of Agricultural Engineering Bornim: „Appproaching Agricultural Technology ond Economic Development of Central and Eastern Europe“. Bornimer Agrartechnische Bearichte, No 27 (page 19-24). PotstadmBornim.

10. Ivkov, I., Todorović, S., Munćan, M. (2008): Bruto marža kao značajan pokazatelj poslovanja poljoprivrednih gazdinstava, Tematski zbornik ,Agroekonomska nauka i struka u tranziciji obrazovanja i agroprivrede" pp. 235-242, 24-25 oktobar, Poljoprivredni fakultet, Beograd. 
11. Kovacs, G., Nagy, I., Takacs, I. (2003): Connection between virtual and real large-scale agricultural Entreprises. u Large Farm Management, Studies on the Agricultural and Food Sector in Central and Europe, Vol. 20, page 207-227, Bergen/ Dumme:Agrimedia GMBh.

12. Mihajlović, M.(2016): Odnos menadžmenta preduzeća i korporativnog upravljanja, Oditor, Vol. 2, No. 1, pp. 4-10.

13. Munćan, M., Todorović, S., Ivkov, I. (2008): Model porodičnog gazdinstva kao osnova za eksperimentisanje u agroekonomskim istraživanjima. Tematski zbornik: „Agroekonomska nauka i struka u tranziciji obrazovanja i agroprivrede“, pp. 211 221, 24-25 oktobar, Poljoprivredni fakultet, Beograd.

14. Munćan, P. (2011): Zavisnost dohotka porodičnih gazdinstava od veličine poseda i strukture ratarske proizvodnje, Ekonomika poljoprivrede, No. SB-2, pp. 51-61, Institut za ekonomiku poljoprivrede, Beograd.

15. Munćan, P., Todorivić, S., Munćan, M. (2014): Profitability of Family Farms Directed at Crop Poduction Economics of Agriculture, No 3, pp. 575-585, Belgrade.

16. Todorović, S., Munćan, M., Miljković, M. (2009): “The growing importance of activities diversification for enhancing family farms competitiveness", Thematic Proceedings - 113th Seminar of the EAAE "The role of knowledge, innovation and human capital in multifunctional agriculture and territorial rural development", page 331-336; 9-11 december Institute of Agricultural Economics, Belgrade.

17. Todorović, S., Ivanović, S., Munćan, M. (2011): Mogućnosti povećanja uposlenosti radne snage na porodičnim gazdinstvima promenom smera proizvodnje, Ekonomika poljoprivrede, SB-2, pp. 105-124, Institut za ekonomiku poljoprivrede, Beograd.

18. Todorović, S. (2014): Mogućnosti unapređenja konkurentnosti porodičnih gazdinstava usmerenih na ratarsku proizvodnju, neobjavljen magistarski rad, Poljoprivredni fakultet, Beograd.

19. Vidović, Z., Milunović, M. (2017): Revizija svrsishodnosti poslovanja, Oditor, Vol. 3, No. 2, pp. 37-53. 


\title{
VELIČINA GAZDINSTVA KAO FAKTOR ZAPOSLENOSTI I DOHOTKA ČLANOVA PORODIČNIH GAZDINSTAVA
}

\section{Petar Munćan ${ }^{7}$ Dragica Božićc ${ }^{8}$}

\begin{abstract}
Apstrakt
Na osnovu podataka prikupljenih metodom ankete na 35 porodičnih gazdinstava sa područja Vojvodine specijalizovanih na tržišno orijentisanu ratarsku proizvodnju u ovom radu je ispitivana međuzavisnost veličine porodičnih gazdinstava $i$ strukture ratarske proizvodnje na zaposlenost aktivnih članova stalno zaposlenih u poljoprivredi $i$ njihov dohodak. Ustanovljeno je da se sa povećanjem veličine gazdinstva sa 20 na 100 ha povećava iskorišćenost raspoloživog fonda radnog vremena aktivnih članova stalno zaposlenih u poljoprivredi za skoro 2 puta. Pored toga, sa povećanjem veličine gazdinstva i povećanjem učešća industrijskih biljaka u strukturi setve, dohodak po aktivnom članu gazdinstva stalno zaposlenom u poljoprivredi takođe ispoljava tendenciju porasta. Na gazdinstvima veličine 50-100 ha dohodak po aktivnom članu 3,6 puta je veći od dohotka ostvarenog na gazdinstvima veličine poseda 10-20 ha.
\end{abstract}

Ključne reči: porodično gazdinstvo, struktura proizvodnje, aktivni članovi gazdinstva, zaposlenost, dohodak

7 Dr Petar Munćan, redovni profesor; Univerzitet u Beogradu, Poljoprivredni fakultet, Beograd-Zemun, 011 2615-315 e-mail: muncan@agrif.bg.ac.rs

8 Dr Dragica Božić, redovni profesor; Univerzitet u Beogradu, Poljoprivredni fakultet, Beograd-Zemun , 011 2615-315 e-mail: bozdrag@agrif.bg.ac.rs 
ECONOMICS OF

AGRICULTURE

\section{CONTENT}

1. Adriana Radosavac, Desimir Knežević

ECONOMIC IMPORTANCE OF USE

OF PESTICIDES IN WHEAT PRODUCTION . . . . . . . . . . . 1323

2. Berhe Gebregewergs, Muuz Hadush

DOES CLIMATE CHANGE AFFECT PRICE OF VEGETABLES:

EVIDENCE FROM TIGRAI, NORTHERN MOST ETHIOPIA. . . . .1335

3. Grujica Vico, Aleksandra Govedarica-Lučić, Zoran Rajić, Radomir Bodiroga, Ivan Mičić, Silvija Zec Sambol, Marija Mičić

MULTI ATTRIBUTE ASSESSMENT APPROACH

IN VEGETABLE PRODUCTION . . . . . . . . . . . . . . 1355

4. Igor Trandafilović, Vesna Conić, Aleksandra Blagojević

IMPACT OF DEMOGRAPHIC FACTORS ON

ENVIRONMENTALLY CONSCIOUS PURCHASE BEHAVIOUR. . .1365

5. Imre Milán Harcsa

STUDY ON THE POTENTIAL OF SUBCONTRACT

PALINKA DISTILLATION . . . . . . . . . . . . . . 1379

6. Jelena Andrašić, Vera Mirović, Nada Milenković, Branimir Kalaš, Miloš Pjanić

IMPACT OF TAKEOVER PROCESS ON EMPLOYEES -

EVIDENCE FROM FOOD, RETAIL AND FINANCIAL SECTOR . . .1393

7. Jelena Birovljev, Danilo Đokić, Bojan Matkovski, Žana Kleut

ECONOMIC PERFORMANCES OF AGRICULTURE

OF CEFTA AND FORMER CEFTA COUNTRIES . . . . . . . . . . 1413

8. Jelena Marković, Svetlana Stevović

SUSTAINABILITY OF CHEMICAL SOIL QUALITY

IN SOUTHERN MORAVA RIVER VALLEY

IN CORELLATION WITH THE FLOODING $\ldots \ldots \ldots \ldots \ldots$ 
9. Mile Peševski, Zoran Milovančević

THE CHANGES IN THE USAGE OF AGRICULTURAL LAND

IN EASTERN REGION OF REPUBLIC OF MACEDONIA

BETWEEN $1991-2030 \ldots \ldots$. . . . . . . . . . . . . . . . . . . . . . .

10. Odjuvwuederhie Emmanuel Inoni, 'Oraye Dicta Ogisi, Felix Odemero Achoja

PROFITABILITY AND TECHNICAL EFFICIENCY IN HOMESTEAD

CATFISH PRODUCTION IN DELTA STATE, NIGERIA . . . . . . . 1449

11. Olja Munitlak - Ivanović, Jovan Zubović, Petar Mitić

RELATIONSHIP BETWEEN SUSTAINABLE DEVELOPMENT AND

GREEN ECONOMY - EMPHASIS ON GREEN FINANCE

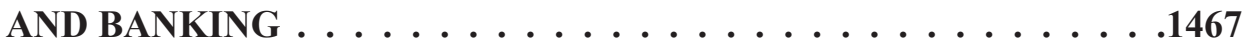

12. Petar Munćan, Dragica Božić

FARM SIZE AS A FACTOR OF EMLOYMENT AND INCOME

OF MEMBERS OF FAMILY FARMS . . . . . . . . . . . . . 1483

13. Rade Popović, Mira Kovljenić

EFFICIENCY OF WHEAT PRODUCTION ON FARMS

IN THE REPUBLIC OF SERBIA . . . . . . . . . . . . . . . . . . . . . . . . .

14. Radovan Damnjanović, Snežana Krstić, Milena Knežević, Svetislav Stanković,

Dejan Jeremić

THE DISCRIMINANT ANALYSIS APPLIED TO THE

DIFFERENTIATION OF SOIL TYPES . . . . . . . . . . . . 1513

15. Slavica Otović, Dunja Demirović, Kristina Košić, Aleksandra Vujko

FOSTERING ENTERPRENUERSHIP AT HIGH SCHOOLS:

A CASE OF RURAL AREAS IN VOJVODINA (SERBIA) . . . . . . .1523

16. Vladimir Ilić, Ivan Bauer, Anastazija Tanja Đelić, Aleksandar Nešković

INSTITUTIONAL SUPPORT FOR STRENGTHENING

ENTREPRENEURSHIP IN AGRICULTURAL PRODUCTION

OF THE REPUBLIC OF SERBIA . . . . . . . . . . . . . . . . . . . . . . . .

17. Boro Krstić, Zorica Vasiljević, Miroslav Nedeljković

INSURANCE CONTRACT AS THE BASIS FOR THE SAFETY OF

AGRICULTURAL PRODUCERS IN THE REPUBLIC OF SRPSKA • . 1555

18. Dejan Sekulić, Aleksandar Petrović, Vladimir Dimitrijević

WHO ARE WINE TOURISTS? AN EMPIRICAL INVESTIGATION

OF SEGMENTS IN SERBIAN WINE TOURISM . . . . . . . . . . . . . 
19. Milan Beslać, Ćorić Goran

FINANCIAL AND PRODUCTION ASPECTS OF GENETICALLY MODIFIED ORGANISMS $\ldots \ldots \ldots \ldots \ldots \ldots \ldots \ldots \ldots$

20. Mlađan Maksimović, Darjan Karabašević, Miodrag Brzaković, Pavle Brzaković THE EFFECTS RESULTING FROM THE APPLICATION OF THE CONCEPT OF THE SUSTAINABLE DEVELOPMENT OF RURAL TOURISM ON STARA PLANINA . . . . . . . . . . . . . . . .1595

21. Vesna Popović, Predrag Vuković, Milivoje Ćosić FOOD SAFETY AND QUALITY POLICY IN THE REPUBLIC OF SERBIA . . . . . . . . . . . . . . . . 1607

22. Radovan Pejanović, Danica Glavaš-Trbić, Mirela Tomaš-Simin PROBLEMS OF AGRICULTURAL AND RURAL DEVELOPMENT IN SERBIA AND NECESSITY OF NEW AGRICULTURAL POLICY . . . .1619

23. Saša Marković, Slavoljub Vujović, Aleksandar Damnjanović MARKETING AND HIGHER EDUCATION CONDITION IN SERBIA . . . . . . . . . . . . . . . . 1635

24. Semir Vehapi, Marina Milanović THE EFFECT OF MARKET ORIENTATION ON BUSINESS PERFORMANCE OF SERBIAN ORGANIC PRODUCERS . . . . . 1651

25. Suad Bećirović, Šemsudin Plojović, Enis Ujkanović, Senadin Plojović CHALLENGES AT STARTING AN AGRIBUSINESS IN THE HILLY MOUNTAINOUS REGIONS OF SOUTHWEST SERBIA . . . . . . . .1669

26. Vladimir Zakić, Vlado Kovačević, Jelena Damnjanović SIGNIFICANCE OF FINACIAL LITERACY FOR THE AGRICULTURAL HOLDINGS IN SERBIA . . . . . . . . . . 1687

27. Željko Bjelajac, Marijana Dukić Mijatović, Željko Vojinović PROTECTION OF LAND IN THE REPUBLIC OF SERBIA AND ECOLOGICAL SECURITY WITH REGARD TO STRATEGIC AND LEGAL FRAMEWORKS . . . . . . . . . .1703 